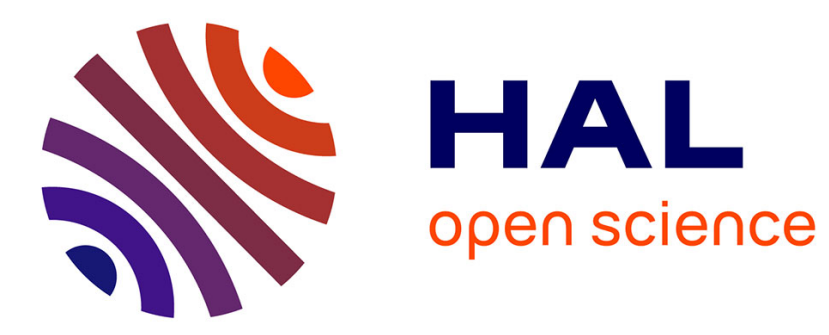

\title{
An extended tetrathiafulvalene redox-ligand incorporating a thiophene spacer
}

Gaëlle Trippé, David Canevet, Franck Le Derf, Pierre Frère, Marc Sallé

\section{To cite this version:}

Gaëlle Trippé, David Canevet, Franck Le Derf, Pierre Frère, Marc Sallé. An extended tetrathiafulvalene redox-ligand incorporating a thiophene spacer. Tetrahedron Letters, 2008, 49 (38), pp.5452 5454. 10.1016/j.tetlet.2008.07.005 . hal-03343422

\section{HAL Id: hal-03343422 \\ https://univ-angers.hal.science/hal-03343422}

Submitted on 14 Sep 2021

HAL is a multi-disciplinary open access archive for the deposit and dissemination of scientific research documents, whether they are published or not. The documents may come from teaching and research institutions in France or abroad, or from public or private research centers.
L'archive ouverte pluridisciplinaire HAL, est destinée au dépôt et à la diffusion de documents scientifiques de niveau recherche, publiés ou non, émanant des établissements d'enseignement et de recherche français ou étrangers, des laboratoires publics ou privés. 


\title{
An extended tetrathiafulvalene redox-ligand incorporating a thiophene spacer
}

\author{
Gaëlle Trippé, David Canevet, Franck Le Derf, Pierre Frère *, Marc Sallé * \\ Université d'Angers, CIMA UMR CNRS 6200, UFR Sciences, 2 boulevard Lavoisier, 49045 Angers, France
}

\section{A R T I C L E I N F O}

\section{Article history:}

Received 3 May 2008

Revised 28 June 2008

Accepted 1 July 2008

Available online 4 July 2008

\section{Keywords:}

Thiophene

Tetrathiafulvalene

Redox-responsive ligand

Electrochemical

Crown-ether

\begin{abstract}
A B S T R A C T
An extended tetrathiafulvalene derivative incorporating a thiophene spacer and a fused crown-ether unit has been synthesized. This highly delocalized system exhibits remarkable electrochemical recognition properties for $\mathrm{Na}^{+}$and $\mathrm{Ba}^{2+}$ as shown by cyclic voltammetry in methylene chloride. This result is attributed to the proximity between the guest metal cation and the positive charge of the oxidized ligand, which is located on the central conjugated thiophenic part.
\end{abstract}

(c) 2008 Elsevier Ltd. All rights reserved.
Redox-responsive ligands ${ }^{1-5}$ are built from the association of a binding unit and an electroactive moiety (ferrocene, quinone, tetrathiafulvalene (TTF), etc.). In this context, a broad range of TTF-based receptors presenting various binding sites have been described, ${ }^{6-9}$ such as crown-ether derivatives ${ }^{10-13}$ or receptors with a coordinating acyclic domain. ${ }^{14-16}$ The recognition process between the receptor and a cationic guest is accompanied by a modification of the redox potentials of the TTF unit, resulting in an electrochemical sensing of the binding event. Anion sensing has also been recently described from analogous TTF-based systems incorporating suitable binding units. ${ }^{17-24}$ One important interest of TTF-based systems lies in their two fully reversible one electron oxidation steps $\left(\mathrm{Ep}_{\mathrm{a}}^{1}, \mathrm{Ep}_{\mathrm{a}}^{2}\right)$, which are associated to three stable oxidation states. Therefore, the binding ability of these host assemblies can be tuned as a function of the oxidation state of the electroactive TTF part. ${ }^{15}$ Another interest of the TTF unit resides on chemical structural flexibility, which allows to tune the redox potentials of the electroactive signalling unit by a suitable substitution on the periphery, or by insertion of a $\pi$-conjugated spacer between the 1,3-dithiol-2-ylidene rings. ${ }^{25,26}$ In that case, a strong modification of the charge distribution is observed in the donating molecule, which explains why $\pi$-extended TTF structures have been extensively explored in particular as precursors for the preparation of solid-state electroconducting cation radical salts, ${ }^{27-29}$ or as strong donating (D) counterparts in donor-acceptor (D-A) dyads. ${ }^{30}$ Extended-TTF skeletons are much rarely found in redoxactive receptors. Considering that recognition process with

\footnotetext{
* Corresponding authors. Tel.: +33 2417354 39; fax: +33 241735405 (M.S.).

E-mail addresses: pierre.frere@univ-angers.fr (P. Frère), marc.salle@univangers.fr (M. Sallé).
}

redox-responsive ligands is strongly dependent on electrostatic interactions occurring between the guest cation and the electroactive unit, it is of strong interest to study the case in which the redox moiety consists in an extended-TTF derivative. One case is $\mathbf{A},{ }^{31}$ and related polyether derivatives which have been described recently. ${ }^{32}$ Also, a crown-ether vinylogous TTF receptor $\mathbf{B}$ has been very recently used for tuning molecular movements, ${ }^{33}$ and a new extended TTF-based receptor $\mathbf{C}$ presenting two pyridyl functional groups for guest coordination has been built by inserting a furano-quinonoid spacer between both 1,3-dithiol-2-ylidene rings. ${ }^{34}$

It is well established that the nature of the conjugated spacer in extended-TTF derivatives has a strong influence on the electrochemical properties of the $\pi$-donors. ${ }^{27}$ In particular, insertion of a

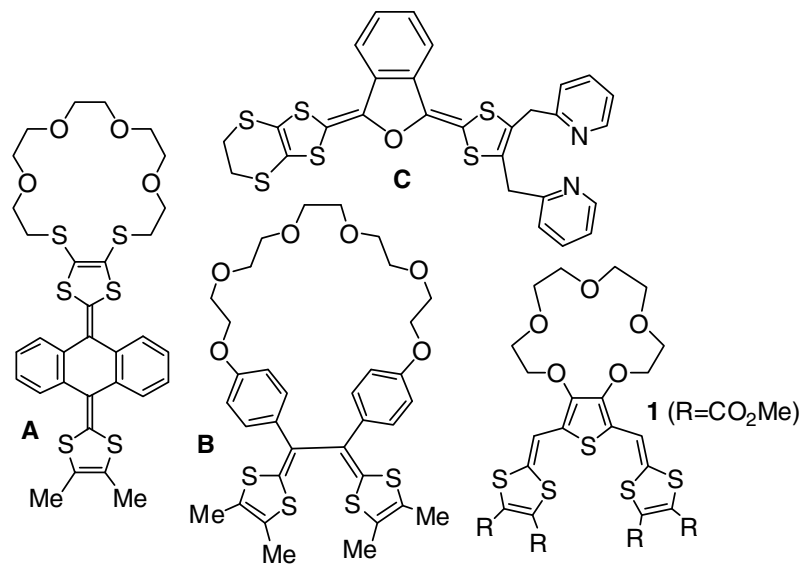



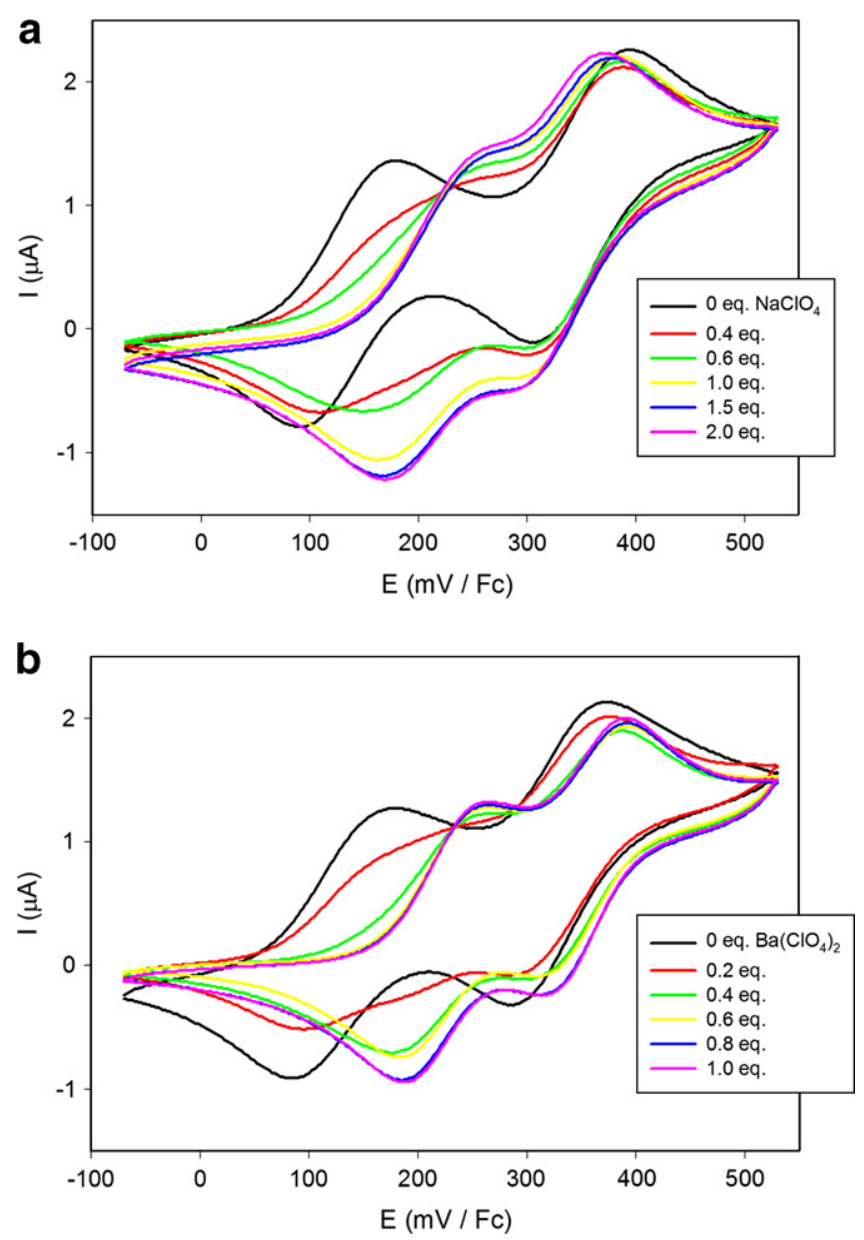

Figure 1. Cyclic voltammograms of $1\left(10^{-3} \mathrm{~mol} \mathrm{~L}^{-1}\right.$ in $0.1 \mathrm{M} \mathrm{Bu}_{4} \mathrm{NPF}_{6}$ in $\left.\mathrm{CH}_{2} \mathrm{Cl}_{2}\right)$ in the presence of increasing amounts of $\mathrm{NaClO}_{4}(\mathrm{a})$ and $\mathrm{Ba}\left(\mathrm{ClO}_{4}\right)_{2}$ (b); vs $\mathrm{Fc} / \mathrm{Fc}^{+}$.

thiophene ring as a spacer has been achieved, ${ }^{35,36}$ and the reversible electrochemical properties of these $\pi$-donors ${ }^{28}$ make this extended skeleton a suitable candidate as an electroactive moiety in redox sensors. Finally, it has been demonstrated that crownethers fused to thiophene units present a good ability to recognize alkali ions in corresponding polythiophene and oligothiophene systems. ${ }^{37-41}$

In this context, recent reports on ligands $\mathbf{B}$ and $\mathbf{C}$ prompt us to report the synthesis and the recognition properties of a molecular receptor 1, presenting a thiophene-based extended-TTF skeleton as the redox-active unit.

Diester derivative $\mathbf{3}$ was synthesized according to the literature procedure, ${ }^{42}$ by [1+1] cyclocondensation of 3,4-dihydroxythiophene-2,5-dicarboxylate $\mathbf{2}$ with tetraethylene glycol ditosylate in the presence of CsF (Scheme 1). Reduction using lithium aluminium hydride afforded diol 4 in $45 \%$ yield. Conversion to the 2,5 diformyl thiophene derivative $\mathbf{5}$ was carried out using pyridinium dichromate (40\%). Note that attempts to directly reduce diester 35 with Dibal-H failed. The final step involves a double Wittig-type olefination of 5 with an excess of the phosphonium-ylid $6^{43}$ bearing a 1,3-dithiol moiety, in the presence of triethylamine. The target compound $\mathbf{1}$ was obtained as a red powder, in good yields (70\%) considering the double olefination step. ${ }^{44}$

Redox properties of $\mathbf{1}$ have been evaluated by cyclic voltammetry (CV) in methylene chloride (Fig. 1). As expected, ligand 1 presents two fully reversible monoelectronic oxidation processes (Table 1), corresponding to the successive formation of cation radical and dication species.

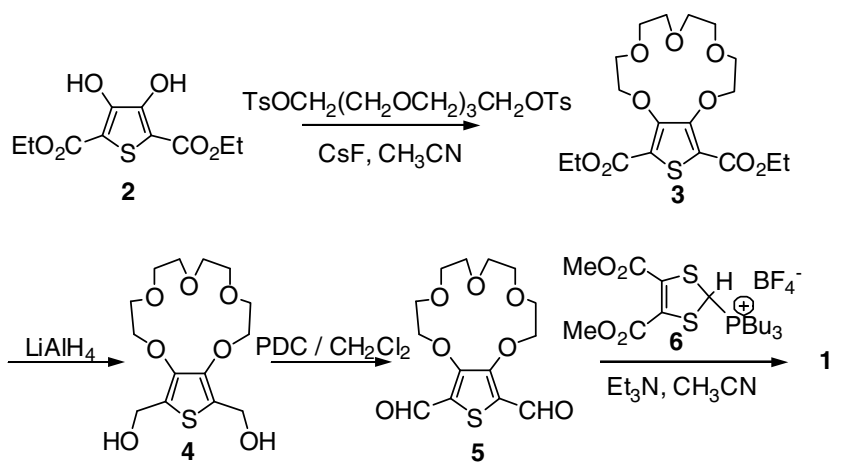

Scheme 1.

Table 1

Peak-potentials versus $\mathrm{Fc} / \mathrm{Fc}^{+}, \quad \mathrm{C}=10^{-3} \mathrm{~mol} \mathrm{~L}^{-1}$ in $\mathrm{CH}_{2} \mathrm{Cl}_{2} \quad\left(\mathrm{Bu}_{4} \mathrm{NPF}_{6}, \quad 0.1 \mathrm{M}\right)$, $v=100 \mathrm{mV} \mathrm{s}^{-1}$, Pt, rt

\begin{tabular}{llll}
\hline & $\mathbf{1}$ & $\mathbf{D}^{45}$ & $\mathbf{E}^{46}$ \\
\hline$E_{\mathrm{ox}}^{1}$ & 0.18 & 0.50 & 0.22 \\
$E_{\mathrm{ox}}^{2}$ & 0.39 & 0.90 & 0.41 \\
\hline
\end{tabular}

$\left.\left.{ }_{\mathrm{MeO}_{2} \mathrm{C}}^{\mathrm{MeO}_{2} \mathrm{C}}\right)_{\mathrm{S}}^{\mathrm{S}}\right\rangle=\left\langle\mathrm{S}_{\mathrm{S}}^{\mathrm{S}} \mathrm{CO}_{2} \mathrm{Me}\right.$

D

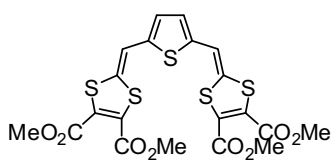

$\mathrm{E}$
Comparison of $\mathbf{1}$ with the reference TTF analogue $\mathbf{D}$ bearing four tetracarbomethoxy substituents is meaningful (Table 1). The significantly lower oxidation potentials observed for $\mathbf{1}$ relative to $\mathbf{D}$ are due to the combined effect of the occurrence of a more extended conjugation in the former case and the presence of donating alkoxy substituents at the 3,4-positions of the central thiophene ring. The difference between the two oxidation potentials in $1\left(\Delta E_{2-1}=E_{\mathrm{ox}}^{2}-E_{\mathrm{ox}}^{1}=210 \mathrm{mV}\right)$ is lower than the value observed for $\mathbf{D}\left(\Delta E_{2-1}=400 \mathrm{mV}\right) .^{45}$ Indeed, extension of the conjugated spacer between both dithiole units favors the access to the dication state by decreasing the coulombic repulsion between both positive charges. Conversely, the value of $\Delta E_{2-1}$ for $\mathbf{1}$ is higher than for the parent system $\mathbf{E}^{46}$ devoid of any substituent on the central thiophene ring $\left(\Delta E_{2-1}=190 \mathrm{mV}\right)$. This observation indicates that in the case of $\mathbf{1}$, a larger coulombic repulsion exists in the dication state. A similar effect was also observed for extended-TTFs built with a 3,4-dialkoxythiophene unit as the spacer, and reveals a tendency for the oxygen atoms directly linked to the thiophene moiety, to localize positive charge in the central position. ${ }^{47}$

Such an electrochemical characteristic is of course of importance when considering the context of redox-responsive ligands, for which electrostatic effects between a bound cation and the electroactive unit play a crucial role.

Binding ability of receptor 1 for various cations was studied by $\mathrm{CV}\left(\mathrm{CH}_{2} \mathrm{Cl}_{2}, \mathrm{Bu}_{4} \mathrm{NPF}_{6} 0.1 \mathrm{~mol} \mathrm{~L}^{-1}\right)$. Important modifications could be observed upon addition of increasing amounts of $\mathrm{NaClO}_{4}$ or $\mathrm{Ba}\left(\mathrm{ClO}_{4}\right)_{2}$. Addition of controlled amounts of sodium perchlorate caused a strong positive shift $\left(\Delta E_{\mathrm{ox}}^{1}=+90 \mathrm{mV}\right)$ of the first oxidation potential $\left(E_{\mathrm{ox}}^{1}\right)$, whereas $E_{\mathrm{ox}}^{2}$ remained approximately constant (Fig. 1a). The reason why the first oxidation wave is shifted to more anodic potentials is explained by the electrostatic inductive effect promoted by the bound metal cation, which decreases the $\pi$-donating ability of the adjacent redox unit. Such a positive shift of $\Delta E_{\text {ox }}^{1}$ is remarkably high and comparable to the highest values reported for TTF-based redox-responsive ligands. This result is 
attributed to the localization of the positive charge in $\mathbf{1}^{+}$on the median thiophene ring ${ }^{47}$ (see above), that is near the bound cationic guest. On the other hand, the constant value of $E_{\text {ox }}^{2}$ upon addition of sodium cation indicates that for the dicationic stage $\left(\mathbf{1}^{2+}\right)$, expulsion of the metal cation outside from the polyethercavity takes place, because of the repulsive electrostatic interaction. A very similar electrochemical behaviour was observed for $\mathbf{1}$ in presence of $\mathrm{LiClO}_{4}$ (see Supplementary data) $\left(\Delta E_{\mathrm{ox}}^{1}=+55 \mathrm{mV}\right.$, $\Delta E_{\mathrm{ox}}^{2} \approx 0.0 \mathrm{mV}$. Also, the addition of a group II cation $\left(\mathrm{Ba}\left(\mathrm{ClO}_{4}\right)_{2}\right)$ is accompanied by an electrochemical signature $\left(\Delta E_{\mathrm{ox}}^{1}=\right.$ $+90 \mathrm{mV}, \Delta E_{\mathrm{ox}}^{2} \approx 0.0 \mathrm{mV}$ ) (Fig. $1 \mathrm{~b}$ ). In this case, no additional evolution of the $C V$ was observed for more than 0.5 equiv in barium perchlorate, which suggests a 2:1 stoichiometry for the corresponding complex.

UV-vis titration experiments were also carried out with receptor $\mathbf{1}$ in the presence of alkali and alkali earth cations (see Supplementary data). In methylene chloride, the addition of controlled amounts of sodium perchlorate up to 1 equiv provokes a strong variation of the shape of the absorption band with in particular the decreasing of the vibronic fine structure and the formation of isosbestic points. For more than 1 equiv, no significant additional modification of the absorption spectrum is observed. In presence of $\mathrm{Ba}\left(\mathrm{ClO}_{4}\right)_{2}$, the change in the spectrum is similar with, in this case, an evolution of the absorption band until the addition of 0.5 equiv, as expected for the $2: 1$ stoichiometry observed by the CV study. On the other hand, no metal complexation occurs in more polar solvents, as shown by the absence of any evolution by addition of sodium or barium cation with $\mathrm{CH}_{3} \mathrm{CN}$ as solvent.

Attempts for reproducing these results by ${ }^{1} \mathrm{H}$ NMR failed because the resulting complex precipitates at NMR concentrations in the NMR tube, when using a chlorinated solvent $\left(\mathrm{CDCl}_{3}, \mathrm{CD}_{2} \mathrm{Cl}_{2}\right)$. Conversely, use of a more solvating mixture $\left(\mathrm{CDCl}_{3}-\mathrm{CD}_{3} \mathrm{CN} ; 1 / 1\right)$ did not allow observation of any chemical shift upon introduction of a metallic salt $\left(\mathrm{NaClO}_{4}, \mathrm{Ba}\left(\mathrm{ClO}_{4}\right)_{2}\right)$.

In summary, we have presented a synthetic access to a redoxresponsive ligand built around an extended tetrathiafulvalene unit incorporating a thiophene ring as spacer. The electrochemical recognition properties for $\mathrm{Na}^{+}$and $\mathrm{Ba}^{2+}$ are remarkable in methylene chloride. This ability to electrochemically detect a guest cation is assigned to the conjunction of a suitable location of the binding site related to the redox unit, associated to a contribution of the electrodonating $\mathrm{O}$-atoms which are directly connected to the central conjugated thiophene spacer.

\section{Acknowledgements}

The authors thank the PIAM of the University of Angers for analytical characterizations; MS is indebted to the Institut Universitaire de France.

\section{Supplementary data}

Uv-vis and CV titration studies of receptor 1 in presence of alkali and alkali earth cations. Supplementary data associated with this article can be found, in the online version, at doi:10.1016/ j.tetlet.2008.07.005.

\section{References and notes}

1. Kaifer, A. E.; Mendoza, S. In Comprehensive Supramolecular Chemistry, Atwood, J. L., Davies, J. E., MacNicol, D. D., Vögtle F., Eds.; Pergamon: Oxford, 1996; Vol. 1, pp 701-732.

2. Boulas, P. L.; Gomez-Kaifer, M.; Echegoyen, L. Angew. Chem., Int. Ed. 1998, 37, 216-247.

3. Beer, P. D.; Gale, P. A.; Chen, G. Z. Coord. Chem. Rev. 1999, 185-186, 3-36.

4. Beer, P. D.; Gale, P. A.; Chen, G. Z. J. Chem. Soc., Dalton Trans. 1999, 1897-1910.

5. Bernhardt, P. V.; Moore, E. G. Aust. J. Chem. 2003, 56, 239-258.

6. Bryce, M. R. J. Mater. Chem. 2000, 10, 589-598.
7. Nielsen, M. B.; Lomholt, C. J. B. Chem. Soc. Rev. 2000, 29, 153-164.

8. Martín, N.; Segura, J.-L. Angew. Chem., Int. Ed. 2001, 40, 1372-1409.

9. Jeppesen, J. O.; Becher, J. Eur. J. Org. Chem. 2003, 17, 3245-3266.

10. Le Derf, F.; Mazari, M.; Mercier, N.; Levillain, E.; Richomme, P.; Becher, J.; Garin, J.; Orduna, J.; Gorgues, A.; Sallé, M. Inorg. Chem. 1999, 38, 6096-6100.

11. Le Derf, F. L.; Mazari, M.; Mercier, N.; Levillain, E.; Richomme, P.; Becher, J.; Garin, J.; Orduna, J.; Gorgues, A.; Sallé, M. Chem. Commun. 1999, 1417-1418.

12. Le Derf, F.; Mazari, M.; Mercier, N.; Levillain, E.; Trippé, G.; Riou, A.; Richomme P.; Becher, J.; Garin, J.; Orduna, J.; Gallego-Planas, N.; Gorgues, A.; Sallé, M. Chem. Eur. J. 2001, 7, 447-455.

13. Trippé, G.; Levillain, E.; Le Derf, F.; Gorgues, A.; Sallé, M.; Jeppesen, J. O. Nielsen, K.; Becher, J. Org. Lett. 2002, 4, 2461-2464.

14. Johnston, B.; Goldenberg, L. M.; Bryce, M. R.; Kataky, R. J. Chem. Soc., Perkin Trans. 2 2000, 189-190.

15. Lyskawa, J.; Le Derf, F.; Levillain, E.; Mazari, M.; Sallé, M.; Dubois, L.; Viel, P.; Bureau, C.; Palacin, S. J. Am. Chem. Soc. 2004, 126, 12194-12195.

16. Trippé, G.; Le Derf, F.; Lyskawa, J.; Mazari, M.; Roncali, J.; Gorgues, A.; Levillain, E.; Sallé, M. Chem. Eur. J. 2004, 10, 6497-6509.

17. Nielsen, K. A.; Sarova, G. H.; Martin-Gomis, L.; Fernandez-Lazaro, F.; Stein, P. C.; Sanguinet, L.; Levillain, E.; Sessler, J. L.; Guldi, D. M.; Sastre-Santos, A.; Jeppesen, J. O. J. Am. Chem. Soc. 2008, 130, 460-462.

18. Zhao, B. T.; Blesa, M. J.; Le Derf, F.; Canevet, D.; Benhaoua, C.; Mazari, M.; Allain M.: Sallé, M. Tetrahedron 2007, 63, 10768-10777.

19. Nielsen, K. A.; Cho, W. S.; Jeppesen, J. O.; Lynch, V. M.; Becher, J.; Sessler, J. L. J. Am. Chem. Soc. 2004, 126, 16296-16297.

20. Lu, H.; Xu, W.; Zhang, D.; Chen, C.; Zhu, D. Org. Lett. 2005, 7, 4629-4632.

21. Lu, H.; Xu, W.; Zhang, D.; Zhu, D. Chem. Commun. 2005, 4777-4779.

22. Zhao, B. T.; Blesa, M. J.; Mercier, N.; Le Derf, F.; Sallé, M. New J. Chem. 2005, 29 1164-1167.

23. Nielsen, K. A.; Cho, W. S.; Lyskawa, J.; Levillain, E.; Lynch, V. M.; Sessler, J. L.; Jeppesen, J. O. J. Am. Chem. Soc. 2006, 128, 2444-2451.

24. Nielsen, K. A.; Cho, W. S.; Sarova, G. H.; Petersen, B. M.; Bond, A. D.; Becher, J.; Jensen, F.; Guldi, D. M.; Sessler, J. L.; Jeppesen, J. O. Angew. Chem., Int. Ed. 2006, 45, 6848-6853.

25. Bendikov, M.; Wudl, F.; Perepichka, D. F. Chem. Rev. 2004, 104, 4891-4945.

26. Gorgues, A.; Hudhomme, P.; Sallé, M. Chem. Rev. 2004, 104, 5151-5184.

27. Frère, P.; Skabara, P. J. Chem. Soc. Rev. 2005, 34, 69-98.

28. Favard, J. F.; Frère, P.; Riou, A.; BenahmedGasmi, A.; Gorgues, A.; Jubault, M.; Roncali, J. J. Mater. Chem. 1998, 8, 363-366.

29. Roncali, J. J. Mater. Chem. 1997, 7, 2307-2321.

30. For representative recent C60-exTTF conjugates, see: (a) Giacalone, F.; Martín N.; Ramey, J.; Guldi, D. M. Chem. Eur. J. 2005, 11, 4819-4834; (b) Handa, S.; Giacalone, F.; Haque, S. A.; Palomares, E.; Martín, N.; Durrant, J. R. Chem. Eur. J. 2005, 11, 7440-7447; (c) Sanchez, L.; Sierra, M.; Martín, N.; Guldi, D. M.; Wienk, M. W.; Janssen, R. A. J. Org. Lett. 2005, 128, 1048-10490; (d) Martín, N. Chem. Commun. 2006, 2093-2104; (e) Atienza, C.; Martín, N.; Wielopolski, M.; Haworth, N.; Clark, T.; Guldi, D. M. Chem. Commun. 2006, 3202-3204.

31. Bryce, M. R.; Batsanov, A. S.; Finn, T.; Hansen, T. K.; Moore, A. J.; Howard, J. A K.; Kamenjicki, M.; Lednev, I. K.; Asher, S. A. Eur. J. Org. Chem. 2001, 5, 933-940.

32. Diaz, M. C.; Illescas, B. M.; Martin, N.; Stoddart, J. F.; Canales, M. A.; JimenezBarbero, J.; Sarova, G.; Guldi, D. M. Tetrahedron 2006, 62, 1998-2002.

33. Massue, J.; Bellec, N.; Guerro, M.; Bergamini, J. F.; Hapiot, P.; Lorcy, D. J. Org. Chem. 2007, 72, 4655-4662.

34. Dolder, S.; Liu, S. X.; Le Derf, F.; Salle, M.; Neels, A.; Decurtins, S. Org. Lett. 2007 9, 3753-3756

35. Benahmed-Gasmi, A.; Frère, P.; Garrigues, B.; Gorgues, A.; Jubault, M.; Carlier R.; Texier, F. Tetrahedron Lett. 1992, 33, 6457-6460.

36. Hansen, T. K.; Lakshmikantham, M. V.; Cava, M. P.; Niziurski-Mann, R. E.; Jensen, F.; Becher, J. J. Am. Chem. Soc. 1992, 114, 5035-5039.

37. Bauerle, P.; Scheib, S. Acta Polym. 1995, 46, 124-129.

38. Bauerle, P.; Mitschke, U.; Gruner, G.; Rimmel, G. Pure Appl. Chem. 1999, 71 2153-2160.

39. Rimmel, G.; Bäuerle, P. Synth. Met. 1999, 102, 1323-1324.

40. Berlin, A.; Zotti, G.; Zecchin, S.; Schiavon, G. Synth. Met. 2002, 131, 149-160

41. Demeter, D.; Blanchard, P.; Grosu, I.; Roncali, J. J. Inclusion Phenom. 2008, 1-13.

42. Sone, T.; Ohba, Y. Bull. Chem. Soc. Jpn. 1989, 62, 838-844.

43. Lakshmikantham, M. V.; Cava, M. P.; Caroll, P. J. J. Org. Chem. 1984, 49, 726-728.

44. All new compounds exhibited spectral properties consistent with the assigned structures: Compound 4: white viscous oil, ${ }^{1} \mathrm{H}$ NMR (500 MHz, $\left.\mathrm{CDCl}_{3}\right): 2.41$ (br $\mathrm{s}, 2 \mathrm{H}, \mathrm{OH}), 3.68\left(\mathrm{br} \mathrm{s}, 8 \mathrm{H}, \mathrm{OCH}_{2}\right), 3.85\left(\mathrm{t}, 4 \mathrm{H}, \mathrm{OCH}_{2}\right), 4.21\left(\mathrm{t}, 4 \mathrm{H}, \mathrm{OCH}_{2}\right), 4.63(\mathrm{~s}$ $\left.4 \mathrm{H}, \mathrm{CH}_{2} \mathrm{OH}\right) ;{ }^{13} \mathrm{C}$ NMR $\left(125.7 \mathrm{MHz}, \mathrm{CDCl}_{3}\right) 56.8,70.5,70.6,71.0,73.3,123.5$, 146.1. Compound 5: pale yellow solid, $\mathrm{mp} 88^{\circ} \mathrm{C}$; ${ }^{1} \mathrm{H}$ NMR $\left(500 \mathrm{MHz}, \mathrm{CDCl}_{3}\right)$ : $3.68\left(\right.$ br s, $\left.4 \mathrm{H}, \mathrm{OCH}_{2}\right), 3.72\left(\right.$ br s, $\left.4 \mathrm{H}, \mathrm{OCH}_{2}\right), 3.92\left(\mathrm{t}, 4 \mathrm{H}, \mathrm{OCH}_{2}\right), 4.52(\mathrm{t}, 4 \mathrm{H}$, $\left.\mathrm{OCH}_{2}\right), 10.06$ (s, 2H, CHO); ${ }^{13} \mathrm{C}\left(125.7 \mathrm{MHz}, \mathrm{CDCl}_{3}\right): 70.0,70.6,70.8,75.1,130.4$, 154.4, 181.9; MS (EI) $330\left[\mathrm{M}^{+*}\right]$. Compound 1: red-orange solid, mp $159{ }^{\circ} \mathrm{C} ;{ }^{1} \mathrm{H}$ NMR $\left(500 \mathrm{MHz}, \mathrm{CDCl}_{3}\right): 3.71\left(\mathrm{~s}, 8 \mathrm{H}, \mathrm{OCH}_{2}\right), 3.85\left(\mathrm{~s}, 6 \mathrm{H}, \mathrm{OCH}_{3}\right), 3.88(\mathrm{~s}, 6 \mathrm{H}$ $\left.\mathrm{OCH}_{3}\right), 3.89\left(\mathrm{t}, 4 \mathrm{H}, \mathrm{OCH}_{2}\right), 4.16\left(\mathrm{t}, 4 \mathrm{H}, \mathrm{OCH}_{2}\right), 6.64(\mathrm{~s}, 2 \mathrm{H},=\mathrm{CH}) ;{ }^{13} \mathrm{C} \mathrm{NMR}$ $\left(125.7 \mathrm{MHz} \mathrm{CDCl}_{3}\right): 53.3,70.3,70.7,71.1,73.6,105.9,122,3,127.1,130.9$ 131.2, 144.8, 159.9, 160.0; HRMS (ESI+) Calcd for $\mathrm{C}_{28} \mathrm{H}_{30} \mathrm{O}_{13} \mathrm{~S}_{5}$ : 734.0290; found: 734.0310 .

45. Nguyen, T.-T.; Gouriou, Y.; Sallé, M.; Frère, P.; Jubault, M.; Gorgues, A.; Toupet L.; Riou, A. Bull. Soc. Chim. Fr. 1996, 133, 301-308.

46. Roncali, J.; Rasmussen, L.; Thobie-Gautier, C.; Frère, P.; Brisset, H.; Sallé, M.; Becher, J.; Simonsen, O.; Hansen, T. K.; Benahmed-Gasmi, A.; Orduna, J.; Garin, J.; Jubault, M.; Gorgues, A. Adv. Mater. 1994, 6, 841.

47. Akoudad, S.; Frère, P.; Mercier, N.; Roncali, J. J. Org. Chem. 1999, 64, 4267-4272. 